\title{
In the state administration system of Indonesia: No space for Khilafah!
}

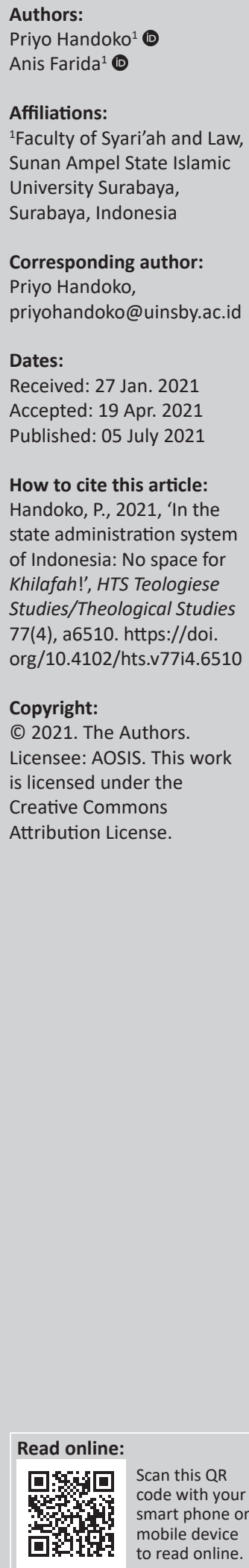

This study aims at reducing, and even eliminating, the thoughts of small Muslim groups in Indonesia, which state that the replacement of Pancasila as a Khilafah will raise the Indonesian state to become a developed country. This study uses a normative legal research methodology with two approaches: a historical and a conceptual approach. The historical approach was used to review the history of the implementation of the Khilafah system in Islam and the early history of the emergence of Pancasila as a national government system. Meanwhile, the conceptual approach was used as a road map to examine the Khilafah and Pancasila concepts in the constitutional system. The results of this study revealed that Pancasila represents the Indonesian nation's ideology, which is in tune with Islamic law, and can answer all the needs of its people. Through Pancasila, the Indonesian people can live in harmony amidst existing pluralism. Therefore, there is no space for ideology other than Pancasila to fill and become the foundation of the Indonesian nation.

Contribution: This article attempts to answer Muslim people's doubts with extremist ideology who want to change Pancasila into Khilafah. No movement seeks to change the Pancasila government system with other government systems.

Keywords: Pancasila; Khilafah; nation ideology; law; state administration.

\section{Introduction}

The Khilafah system is still a hot topic to be discussed in the state administration system in Indonesia. The thoughts, pros and cons concerning the implementation of the Khilafah system in Indonesia triggered this condition.

The pro-argument states that Indonesia's current democratic system cannot provide justice and prosperity to all Indonesians. Likewise, they believe that implementing the Khilafah system can provide justice and prosperity to all Indonesian people. The contra group argues that the implementation of the Khilafah system in Indonesia is not under the Indonesian people's culture. Indonesian society, which tends to be pluralistic, is in tune with implementing the current democratic system, which places Pancasila as its foundation (Munadzir 2017).

These differences of opinion are endless and need to be addressed wisely to reduce the prolonged conflict. It is crucial to eliminate misconceptions circulating biases in society and maintain harmony to create a prosperous nation.

Through this article, the authors want to show the results of a study on the Khilafah system in Indonesia, juxtaposed with Pancasila as the basis of philosophy (philosophische grondslag). The two approaches are measured. The caliphate system is worthy of being used as a guide in running the current wheels of government and state administration. Is it precisely a Pancasila-based democratic system that reflects the diversity, religious values and social values?

\section{Research method and design}

This study is a normative legal research, which makes the basic norms and rules, legal principles, statutory regulations and doctrine as the object (Amiruddin dan Asikin 2004). The approach used in this research is the historical and conceptual approach. The historical approach is used to explore the history of each of the main objects to be studied, while the conceptual approach is employed to analyse the underlying concepts. 
Before providing a review of the above points, the author will describe several similar studies as material from literature reviews. There is a clear distinction between tasks that have previously been carried out to avoid similarities in the primary substance.

Firstly, a research study was conducted by Muzayyin Ahyar with the title, 'Al Mawardi and the concept of KhilafahIslamiyyah: The relevance of classical Islamic political systems and modern politics'. This study uses an approach to political institutionalism in a country. The study results reveal that the classical Islamic political concept's spirit lies in the existence of the distribution of power. In contrast, the modern state concept emphasises the principle of separation of power, so it is no longer relevant that classical Islamic principles are applied to the idea or system of modern state administration (Ahyar 2018).

Secondly, a research study was conducted by Baidhowi with the title, 'Khilafah in the context of the state of Pancasila'. In this research study, it is said that Pancasila as the nation's ideology is the result of exploring the values such as godliness, compassion, living in unity, deliberation and the longing for justice, that live in society. In this case, it must be conveyed and taught to the community. Besides, the public must believe that the Indonesian state was founded by founding people to be united, sovereign, just and prosperous. Therefore, it is not appropriate to conclude that the Indonesian nation's reform shows that the Indonesian state with the Pancasila ideology has failed and must change its ideology (Baidhowi 2016).

Thirdly, an article was written by Komarudin Hidayat with the title, 'The controversy of the caliphate: Islam, state, and Pancasila'. This article clearly describes that Indonesia is a nation state with a commitment to protect and facilitate religious life. Misrawi (2011) stated that Prophet Muhammad SAW never obliged the Khilafah system as the only system in Islam for a form of government (Hidayat 2014). Especially for Indonesia, as a nation state, which is rich in diversity, the idea of changing the Pancasila ideology into a Khilafah system should be a critical study. According to Misrawi (2011), dismantling these ideas' concepts and meaning must be a serious study to establish the proper position. Is it in tune with the Pancasila ideology or not? (Jaelani 2015). The idea of the Khilafah system and ideology has presented various debates that are so long that they have not been completed. A group of people understand that the Khilafah system is an ideal form of life and state. However, not a few argued that the Khilafah system is no longer relevant when implemented in an ideal state administration system, especially in Indonesia.

Since its establishment, the Indonesian state has been based on Pancasila ideology and the 1945 Constitution. Both instruments value and uphold diversity and tolerance. So that in this case, mutatis-mutandis actually already reflects the values contained in Islam. It is in line with Masdar Farid Mas'udi's statement. In the context of the
Unitary State of the Republic of Indonesia (Negara Kesatuan Republik Indonesia [NKRI]), which is based on Pancasila and the 1945 Constitution, it is in line with the form of Khilafah, which is legal according to Islam and the Qur'an. Pancasila and the 1945 Constitution have upheld the spirit and principles of the Khilafah based on Islam and the Qur'an. Besides, what is very important is that the schedule of all Indonesian society elements no longer questions the validity of the conceptual ideology or the constitutional system, but how to do it with sincerity. It is not the time to think debatably related to the nation's doctrine, but what is important is the careful application of the values contained in the current ideology (Jaelani 2015).

This research study will answer the doubts of a group of people who continually want to change the Pancasila ideology into a Khilafah-based ideology in order to provide academic and conceptual enlightenment. This research study will describe several points to sharpen the argument, including (1) the concept of the Khilafah state and its history, (2) Pancasila as Philosophie Groundslagh in the Indonesian constitutional system and (3) Pancasila as a reflection of the embodiment of traditional Islamic values.

\section{Results}

\section{Concept of Khilafah state and its history}

Etymologically, the term Khilafah means 'following'. A person can be following (takhallafa) when that person is behind someone else: the meaning is to follow someone else and take his place. Ali Abdul Raziq stated that a person could follow if that person carries out the primary duties and functions assigned to him, either individually or collectively (Ali 1985).

In general, the Khilafah's meaning has been equated with al-Imamah (leadership) intention, which is overall leadership to carry out religious and government affairs. The following will explain the meaning of the Khilafah, according to experts.

Baidhowi, as quoted by Ali Abdul Raziq, said that Khilafah is a term relating to the replacement of Rasulullah SAW to enforce the laws and regulations and preserve the values of Islamic teachings through a line of command that must be followed (Ali 1985).

Ibn Khaldun stated that the Khilafah is a general responsibility per the objectives of syara' 'to create the benefit of the $u$ khrawi [life after death] and the duniawi [terrestrial] for all people.' Essentially, the caliphate is a substitute for the function of the syara' maker to maintain religious and political issues in the state administration (Kholdun 2000:151).

Al-Maududi defined the Khilafah doctrine as contained in the Al-Qur'an in essence, with the understanding that everything in this world belongs only to Allah; human beings are only obliged to protect it (Al-Maududi 1984). Furthermore, he stated that Islam uses the word Khilafah not for sovereignty. The reason is that in Islam absolute 
freedom belongs only to God alone. Whoever holds power as Khilafah or supreme leader has no authority other than to enforce the provisions limited by God (Al-Maududi 1995).

Taqiyuddin Al-Nabani stated that caliphate is the only system of government for an Islamic state. He defined that the Khalifah, as the leader of an Islamic state, must enforce Syara' laws. What needs to be known is that the Khilafah system is very different from the monarchy, republic, federation and so on, in terms of its establishment, thoughts, concepts and laws used to serve the people. The Khilafah is a practical political doctrine, which is intended to apply and enforce the Islamic law (Al-Nabani 1996).

Based on definitions conveyed by several experts above, we can conclude that the Khilafah system is leadership in Islam as a substitute for the Prophet Muhammad. Besides, there is a clear distinction from other constitutional procedures in the Khilafah system, such as monarchy, republic and federal. Khilafah leadership is a form of leadership oriented towards upholding the Islamic law. The application of Islamic law is not only limited to Muslims but also to all society members in a country. That is why it is opposed by many groups, especially in a country that consists of multiple religions.

Generally, several legal bases have been provided in both the Al-Qur'an and Hadith for implementing the caliphate system in a government. First, we can find it in the Qu'ran:

O you who believe! Obey Allah and obey the Messenger (Muhammad SAW), and those of you (Muslims) in authority. (And) if you differ in anything amongst yourselves, refer it to Allah, and His Messenger SAW, if you believe in Allah and in the Last Day. That is better and more suitable for final determination. (Q.S An-Nisa' [4]:59)

The Qur'an Sura An-Nisa' [4]:59 shows the need for a leader to be used as a reference for solving the problems. If we look carefully, the term Khilafah will not be found in the contents of the letter. However, in this provision, Ulil Amri can be interpreted as saying that the leaders are Rasulullah SAW, Khulafa 'al-Rasyidin, judges, religious leaders, scholars and ahl al-halli wa al-aqdi (Shihab 2007).

Taqiyuddin al-Nabhani stated that Islam had ordered its people to establish a government system and appoint a Khilafah who would govern based on Islamic religious laws (Al-Nabani 1996). It is based on the verse of the Qur'an, which reads as follows:

And we have sent down to you (O Muhammad SAW) the Book (this Qur'an) in truth, confirming the Scripture that came before it and Muhaymin (trustworthy in highness and a witness) over it (old Scriptures). Judge, then, in the affairs of men in accordance with the Law that Allah has revealed, and do not follow their desires in disregard of the Truth which has come to you. To each among you, we have prescribed a law and a clear way. If Allah had willed, He would have made you one nation, but that $(\mathrm{He})$ may test you in what He has given you; so compete in good deeds. The return of you (all) is to Allah; then He will inform you about that in which you used to differ. (Q.S Al-Maidah [5]:48)
From these verses we can find other commands in in the Qur'an (Surah Al-Maidah [5]:49 and Q.S Al-Maidah [5]:44). According to Taqiyuddin, Islam is the state's ideology, which has made the state and its powers an integral and inseparable unit. Islam has encouraged its adherents to establish a state and government, which orders based on syara' laws. According to him, Islam has defined and limited the form of government with the Khilafah system. He emphasised that the Khilafah is the only form of government in an Islamic state (Al-Nabani 1996).

If we look at the historical perspective, the concept of Khilafah in Islamic politics cannot be separated from Prophet Muhammad's death. Prophet Muhammad (peace be upon him) left a leader void who, logically, probably could not be replaced by anyone. Prophet Muhammad's position is the state's leader and prophet, legislator and implementer of these laws (Engineer 1999). Therefore, the Khilafah's discussion as a historical discourse is clearly distinguished from a caliphate's conceptual discussion.

As a historical discourse, the Khilafah is a history applied after Prophet Muhammad's death and was limited to Khulafa 'al-Rasyidin. However, as a conceptual discourse, the Khilafah is a conceptual reality that must be debated and compared with other concepts. Can the caliphate as a concept provide benefits to the current developments? Of course, these things need to be studied in detail and systematically.

Moreover, the development of a country cannot be separated from the character of a nation. Indonesia was founded based on all social elements' welfare. The idea of a caliphate concept that is to be applied in Indonesia certainly needs to be juxtaposed with Pancasila as the foundation of the Indonesian nation's ideology, which is currently being implemented. Therefore, in the following discussion, Pancasila will be discussed comprehensively as the Indonesian nation's way of life, which underlies the Indonesian state's establishment.

\section{Pancasila as a philosophical grondslag in the state administration system in Indonesia}

The position of Pancasila as the basis of the state, as stated in the Preamble to the 1945 Constitution, is essentially a legal ideal (Richtsidee). As a standard ideal, Pancasila has been transformed into the fundamental law, both written and unwritten basic laws. Rudolf Stammler mentioned that the law model is a construction of thought that must direct the law towards an ideal desired by society. The law's objective functions as a guiding star (leitstern) to achieve the community's wishes and aspirations. A legal ideal is essential because, with this standard ideal, the law can be directed towards justice values.

In a modern state, the Indonesian state has carried out legal reforms to uphold democracy that develops constitutionalism principles. The principle of constitutionalism implies that every government's action must be based on the constitution's validity in a country. The constitution has been built on 
the awareness and political consensus by the people's representatives to the welfare of all Indonesian people.

The consensus that guarantees constitutionalism principles during the reform period, therefore, can be classified into three things: firstly, the agreement on common goals and ideals (society's general purpose or general acceptance of the philosophy); secondly, understanding the rule of law as the basis of government or state administration (government); and, thirdly, the agreement on institutional forms and state administration procedures (formation of institutions and policies).

The first agreement, namely, regarding common ideals, dramatically determines the upholding of constitutionalism in a country. In that ideal, abstractionist abstraction's peak allows it to reflect the similarities of resistance between all citizens who have to live amidst pluralism or plurality. Therefore, the Khilafah government system, which requires absolute compliance with the Islamic law from a historical perspective, is very irrelevant to the shared ideals that the Indonesian people are trying to fight.

As an agreement guarantees togetherness in the state life framework, it is necessary to formulate common goals or ideals, often referred to as philosophical grondslag and common platform (or kalimatun sawa) amongst fellow people (Asshiddiqie 2005).

For the Indonesian nation and state, the basis of philosophy life is Pancasila. Pancasila is the core philosophy of the Indonesian state; therefore, the essence of the fundamental normal staat is to reflect Pancasila's values. The actual values contained in the state philosophy are the philosophicalideological basis for realising the ideals of the state, in terms of the objectives of the principle of constitutionalism as a formal law state, the four models of statehood contained in the preamble to the 1945 Constitution, namely, (1) protect the entire nation and all the blood of Indonesia, (2) promote (improve) public welfare, (3) educate the nation's life and (4) participate in implementing world order based on the eternal peace and social justice.

The second is an agreement that the government is based on the rule of law and the Constitution. This agreement is also fundamental because it involves the basics in the life of state administration. It will provide the basis that everything is done in the state's administration; it must be based on the rule of law, which is determined collectively.

The third agreement deals with: (1) the building of state organs and the procedures governing their power, (2) the relationship between these state organs and each other and (3) the relationship between the state organs and citizens. With this agreement, the constitution's contents as the concretisation of Pancasila can be easily formulated because it genuinely reflects the common desire concerning state institutions and state administration mechanisms to be developed within the framework of a constitutional state. These agreements are formulated in constitutional documents, which are expected to become joint holdings for quite an extended period.

Historically, Pancasila is a nation's view of life whose values existed before the founders formed the Indonesian government. God Almighty has historically destined the Indonesian country to become a nation that develops through a long process and finds its form as a nation with its own identity.

According to M. Yamin, the Indonesian nation state formed in three stages: firstly, the Sriwijaya era under the Syailendra dynasty (since 600), characterised by unity; secondly, the national state in Indonesia's Majapahit period was termed as Yamin with the old Indonesian nationality; and, thirdly, the modern nation state, namely, an independent Indonesia (currently the Proclamation of 17 August 1945).

Culturally, the basics of thinking about Pancasila and its values are rooted in the Indonesian nation's cultural and religious values before establishing the state (Notonagoro 1980). As for the process of establishing the state, inspired by world views about the state, Pancasila and the religious values of the Indonesian people were electrically synthesised so that they became a local genius and, at the same time, local wisdom of the Indonesian people.

Basically, Pancasila's values were formed before the formation of the Indonesian state and nation. It was sporadic and fragmentary as the nation's culture spread throughout the archipelago both in the 20th century and before. Indonesians had the opportunity to communicate and acculturate with other cultures.

The founders of this nation and state developed and legalised these values on a state basis and verbally listed them in the preamble of the 1945 Constitution (Poespowardojo 1989).

In this kind of relationship, the materialist causa of Pancasila is rooted in Indonesian cultural values; if I borrow the terms of Margareth Maed, Ralph Linton and Abraham Kardiner in Anthropology to Day, termed the 'National Charter' (Ismaun 1983).

The Indonesian nation's cultural and religious values are then discussed and formulated by the founding fathers of the Indonesian country, which are then agreed upon in a consensus as the basis for living together in an Indonesian state. Notonagoro states that the Indonesian nation's values are a material causa, whilst the makers, such as Badan Penyelidik Usaha-Usaha Persiapan Kemerdekaan Indonesia (BPUPKI) and Panitia Persiapan Kemerdekaan Indonesia (PPKI) is a formalist causa (Kaelan 2017; Notonagoro 1980).

In this connection, according to Andrews (1968), it is said that the establishment of a modern state must be based on a consensus contained in a common goal and goal in a 
philosophical foundation (the general plan of society or public acceptance of the same philosophy of government).

\section{Pancasila as a reflection of the embodiment of Islamic legal values}

As a unitary state with all its pluralistic compositions, Indonesia has affirmed Pancasila as the state ideology. Pancasila results from conceptualisation, internalisation and the long history of the Indonesian nation's struggle. However, extremist groups wish to change Pancasila into a Khilafah state (based on the Islamic law). Members of the group called Pancasila the 'Thagut'. Therefore, in the Discussion section the writer describes and argues that Pancasila is the right ideology and is in tune and in line with Islamic values.

As stated earlier, many nation-building problems have been considered failures in managing and choosing the state ideology. For a group of people acting on behalf of the Muslims in the Unitary State of the Republic of Indonesia, they argue that it is time for the state ideology to be changed from Pancasila to Khilafah Islamiyah (Nashir 2013). This wish has been expressed openly by several Islamic associations or organisations, such as Hizbut Tahrir Indonesia (HTI), the Indonesian Mujahidin Council (MMI) and Jamaah Ansahorut Tauhid (JAT).

These extremist groups firmly state that Pancasila and its three other pillars (Bhineka Tunggal Ika, the Unitary State of the Republic of Indonesia and the 1945 Constitution) are 'Thagut'. Even the first precepts (God Almighty) and four other principles that reflect social monotheism grounded are firmly rejected.

Zakiyuddin Baidhawy stated that they (the extremist group) chose Tauhid Rububiyah, Mulkiyah and Ubudiyah. Some of them carried the tauhid Hakimiyah, which required 'Islamic State' and Islamic Sharia as the state constitution. To achieve their goal, they do not hesitate and do everything they want. It is like distributing a Rubik every Friday containing propaganda (Baidhawy 2010).

The euphoria of the history has shown as if Pancasila vis-à-vis Islamic Shari'at. The euphoria seems to want to show that all this time, the process of government, which is based on the Pancasila ideology, has contradicted the values contained in Islamic Syari'at. According to the extremist group, the Indonesian nation has experienced and plunged into depravity morally, intellectually and spiritually. They believe that with the implementation of Islamic law, the Indonesian government will become a strong nation and will be respected by other countries.

\section{Discussion}

In this section, the forms of internalisation and integration between Islamic law and Pancasila as a philosophy that can accommodate every nation's interest and group, are discussed comprehensively. In order to argue this, the author will first describe the principles of Pancasila and then correlate them with Islamic law so that everything is clear and firm, and will show a balance that Pancasila, which has been used as the nation's ideology, is in tune with and in line with the Islamic law.

\section{The first precept (Ketuhanan Yang MahaEsa or belief in the one and only God)}

Deity comes from God, who is Allah, the creator and ruler of the entire universe. As the first principle, divinity is the primary source of the Indonesian nation's values, which must inspire and guide the manifestation of just and civilised humanity. The first principle emphasises that the Indonesian country and every element of its citizens must recognise God's existence (Mahfud 2012). With this, it has shown that the Indonesian nation is a religious nation state.

Awareness of the Creator's existence has flourished amongst its adherents because religion has long been cultivated and maintained in the society. The government and its people have given faith in life and development. The community is also given the freedom to practise its religion based on its respective beliefs. Article $28 \mathrm{E}$ of the 1945 Constitution of the Republic of Indonesia states that:

Everyone is free to embrace a religion and worship according to his religion, choose education and teaching, choose a job, choose citizenship, choose a place to live in the territory of the country and leave it, and have the right to return. (p. 1, para. 1)

The use of the term 'everyone' in Article 28E suggests that the state does not differentiate between people of different religions or specific groups.

Next, in the first principle, the phrase 'God Almighty' is also a form of local wisdom in embracing the diversity of religions in Indonesia. The first precept has emphasised the Indonesian nation's ethical-religious fundamentals that are rooted in divine moral and religious plurality.

Islam views that the first principle in Pancasila is the basis of faith and monotheism. According to Islam, a religion's dimension lies in each individual, and Islam does not force someone to follow certain beliefs.

Freedom in religious democracy has been clearly stated in Qu'ran (Surah Al-Baqarah [2]:256), which means that 'there is no compulsion for you'. If we look comprehensively, this verse has two legal points of view. Firstly, religious law underlines that there is no compulsion at all to be holy. Secondly, sharia law prohibits pressurising every human being to follow certain faiths based on compulsion.

Zakiyuddin Baidhawy stated that compulsion causes human beings to work under external influence, not the impulse of conscience, to not account for their choices. Coercion also contradicts two things: the will of the Wisest Order Maker and the custodian of those who has a reason, namely, Allah SWT. Also, force or pressure will not 
convey people the truth about the problem. Coercion is also very contrary to reason because it cannot explain the good and bad aspects, nor does it provide a solution for every human being to have the freedom to choose. Forcing humans to believe, apart from being against the will of man (al-Istiqlal), is also against the will of Allah SWT (Baidhawy 2010).

According to Pancasila and the 1945 Constitution of the Republic of Indonesia, Islam also fully supports democratic life in the religious field by protecting the right to freedom of religion and guarantees people freedom to practise religion according to their beliefs. Article 29 paragraph (2) of the 1945 Negara Republik Indonesia (NRI) Constitution states that '[t]he state guarantees every citizen's independence to embrace his or her respective religion and worship according to his religion and belief'.

\section{The second precept (Kemanusiaan Yang Adil dan Beradab or a just and civilised humanity)}

A just and civilised humanity is human attitude and action based on human potential and conscience concerning norms and culture, in general. In principle, this second precept emphasises that the Republic of Indonesia's nationality is part of universal humanity. As a consequence, humans are required to develop brotherhood based on fair and civilised human values. Just and civilised society is the awareness of human attitudes and behaviour based on the potential of reason, character and human conscience. Namely, noble morals are reflected in attitudes, actions and behaviour by human nature and dignity.

According to Islam, civilisation and justice are the main parts of the religious treatise. Islam upholds the tradition of peace and harmony. The second precept in Pancasila also teaches to maintain human values by treating humans fairly and honestly to give birth to civilised, polite and courteous people and both in their actions and words.

Based on the principles of just and civilised humanity, it is therefore suggested that a developed nation is not a nation that has to live alone but a nation that has family ties between nations. The concept is in tune with the Islamic religion's vision, which upholds the value of egalitarianism, namely, an image that is open to solidarity and social dependence (Ta'awun).

Islam respects and recognises all humans' right to live appropriately in various ways without discriminating their social status. The spirit of Islam requires sharing, cooperation and helping each other as stated in the Qur'an (Q.S al-Maidah [5]:2).

\section{The third precept (Persatuan Indonesia or the unity of Indonesia)}

The third precept in Pancasila emphasises that the Indonesian nation is a nation state. It is a nation with a strong desire to be united because of the unity of fate. Unity can mean that the Indonesian nation has extensive diversity and does not mean that it has to carry out the will for equality. It is contained in the state symbol of Pancasila, explicitly written as 'Bhinneka Tunggal Ika'. Unity can also be interpreted as the unity of various backgrounds, such as social, cultural, political, racial, ethnic and religious backgrounds.

In this context, we can understand that Islam is in line with the values in Pancasila because, concretely, Islam teaches about respecting the existence of diversity in a national society. This diversity will create a brotherhood, in which the brotherhood does not recognise the ethnic identity or the embraced religions. The values of the brotherhood have also been found in the Qur'an (QS Yunus [10]:4), which means that '[a]ll Muslims are brothers' and (QS al-Baqarah [2]:213), which means 'and mankind is one people'.

In the context of the life of togetherness, Islam has guided on the importance of ta'aruf and tasamuh. Ta'aruf is a joint effort to know and understand one another (Surah Al-Hujurat [49]:13). It practically comes to the surface in a multicultural collective action. It is an acknowledgment of the plurality of life and an effort to encourage plurality and diversity and, in essence, reinforce diversity and encourage efforts to be equal (equality) and equal dignity (dignity). The implementation and fragmentation of the third precept will give birth to love for the homeland, and have a sense of pride and promote association and diversity (Baidhawy 2010).

\section{The fourth precept (Kerakyatan yang Dipimpin oleh Hikmat Kebijaksanaan dalam Permusyawaratan Perwakilan or democracy guided by the inner wisdom in the unanimity arising out of deliberations amongst representatives)}

The fourth precept in Pancasila emphasises that the Indonesian nation always maintains and develops a deliberation spirit to achieve an agreement. The Indonesian nation still holds and supports democracy to build wisdom in representation. The existence of deliberation can overcome and minimise individuals' arrogance and specific groups to dictate all state policies. Therefore, with this famous principle, the state guarantees that every citizen has an equal position before the law to seek justice and government.

If we examine it more comprehensively, the principle of people is, indeed, in tune with the Islamic law. Islam outlines specific values that can be developed into an institution of people, representing all the people in a country. It also clearly emphasises that there is no theocratic system for managing life. In the context of the state of Indonesia, there is the term 'sovereignty of the people', manifested by the existence of the People's Consultative Assembly as the representative of the people themselves. 
The system of people's sovereignty is the essence of the Islamic message about art in regulating life together. People have the right to demand accountability for implementing the people's sovereignty mandate to this People's Consultative Assembly.

The Islamic concept of Shura manifested in the form of a populist system has accommodated all the constituent elements of democracy. Shura is an institution where every community is given the same right to gather, discuss and negotiate their interests through deliberation to reach a consensus.

The mechanism is intended to examine and select a public suggestion to be filtered as best as possible in line with the state's objectives. Therefore, we can say that shura is a means of deliberation for citizens to fight for their desires. In the context of a state, the shura may not accommodate all the country's aspirations. Still, in this case, it will undoubtedly be chosen according to the priority scale and under the objectives of the country's development. In exchange, people can elect and appoint their representatives to carry out the deliberative function.

\section{The fifth precept (Keadilan Bagi Seluruh Rakyat Indonesia or social justice for the whole of the people of Indonesia)}

In principle, the fifth precept in Pancasila provides guarantees for citizens to live without having a sense of deficiency in the economic aspect. In particular, justice emphasises the principles of justice and economic welfare (social rechtvaardigheid). Sociale rechtvaardigheid can be interpreted as the principle of equality, emancipation and equal participation. What the nation wants lies not only in politics but also in the economic field. Social justice means achieving a balance between the individual life and group or community life.

Besides that, Islam says that justice is the most important manifestation of the first principle of the precepts, namely, God Almighty. The principle of justice is the core of divine moral, the necessary foundation of humanity, the central knot of unity and the dimension of people's sovereignty. As a prophetic treatise, Islam is essentially a call to all humankind to achieve one ideal, namely, unity of humanity, without differentiating between race, skin colour, ethnicity, sex, culture and religion.

As the basis of morality and direction, Pancasila has solid ontological, epistemological and axiological foundations. Each of the principles in Pancasila has a historical, rational and actual justification, which, if understood in detail, will sustain the outstanding achievements of the nation's civilisation.

Philosophically and theologically, Pancasila has clearly shown a consensual relationship between the hablun min Allah and the hablun min al-Nas, which means that these two aspects are a feature of the balance between the state and inspiring

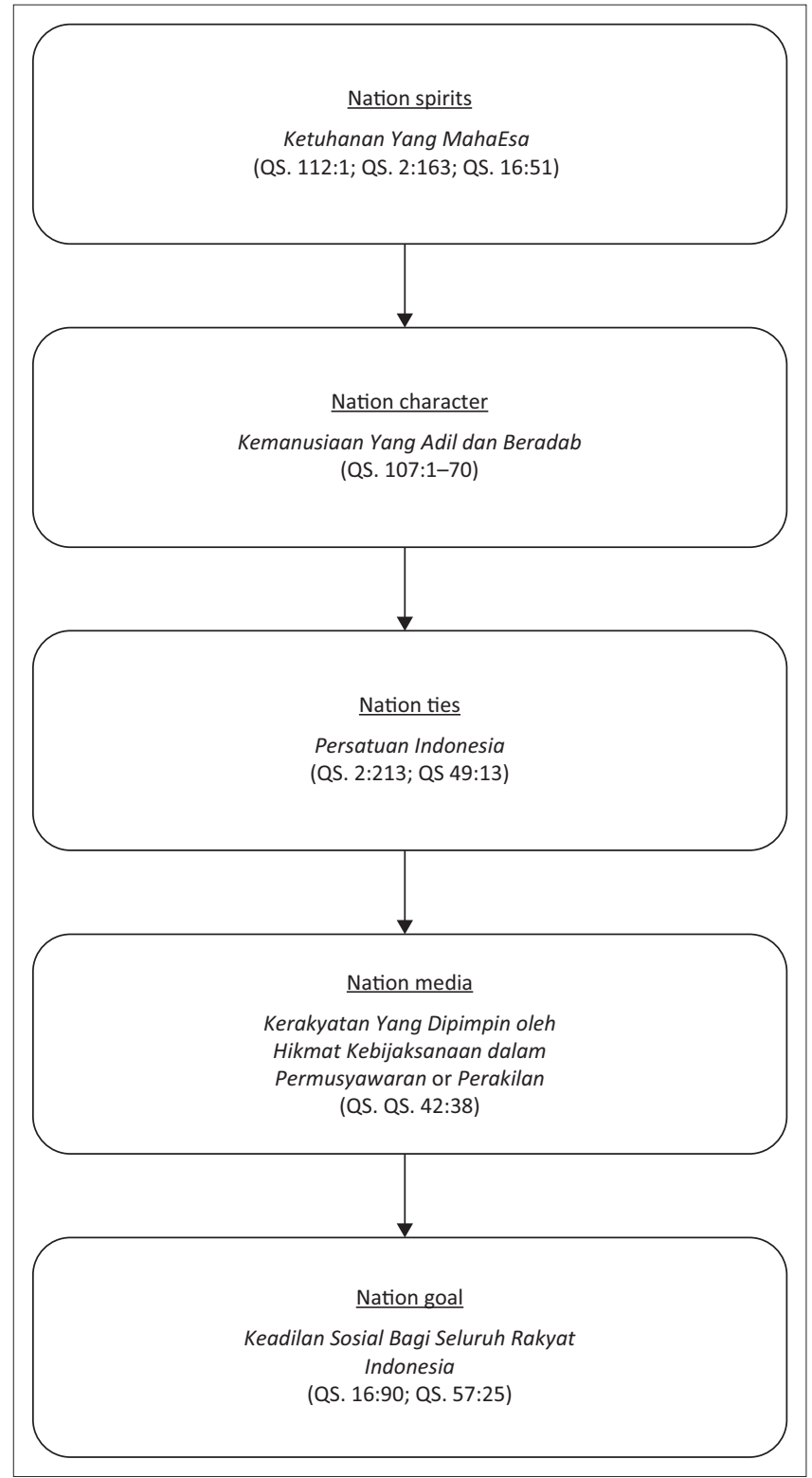

QS, Qur'an Sura.

FIGURE 1: Pancasila in Qur'an verses.

Islamic religious values. Pancasila should be the basis of our common thinking such that, in general, the essential matters of Pancasila do not contradict even with Islam.

As a unitary state that upholds togetherness and pluralism, the state of Indonesia has made efforts to ensure all its people's welfare without any exceptions because the concept of a unitary state contains the meaning of consciousness and diversity, which is in tune with the Qur'an (Q. S al-Hujurat [49]:13).

Pancasila is a form of Islamic objectivation, namely, values that all people generally accept. It indicates that the philosophical-teleological values found in Pancasila do not conflict with Islam or other religions. It includes the vision and mission, as well as the spirit, of Islamic teachings. Therefore, integrating Pancasila values with Islam is very 
important to build a better Indonesian nation. Conceptually, Figure 1 presents the process of integration between Pancasila and Islam.

Based on the processes shown in Figure 1, Indonesian people, mostly Muslims, need not hesitate because Pancasila is a part of Islam's ideological system. Pancasila is not the Taghut ideology conveyed by a group of extremists but an ideology that has integrated the Islamic spirit that all Indonesian society elements can accept.

There is, however, no perfect system in this world, including Pancasila. The repeated cases of rebellion in Indonesia indicate gaps that can be penetrated in the Pancasila system. The gap, according to the author, lies in its plurality. Pancasila will only function if it is applied to a country with a diverse society. Meanwhile, if applied to a homogeneous culture or a specific ruling majority, Pancasila will not be usable. Likewise, with the 1945 Constitution, this is not a 'holy book', so it can be changed and cannot be perfected. There have been several amendments to the 1945 Constitution, from 2000 until now, that can be used as evidence.

\section{Implications and recommendations}

Pancasila has become the basic philosophy of the Indonesian nation, which is under Islamic values. Therefore, there is no longer any reason to change the state government system into other government systems, including the Khilafah government system. Even though Indonesia has the largest Muslim population in the world, given the diversity of the Indonesian nation, the caliphate must be removed, both by the Muslim community itself and by the government in power.

Nevertheless, the political system in Indonesia today, according to the author, has begun to lead to a liberal democratic system, not Pancasila democracy anymore. Why? Because the leader recruitment system in Indonesia, depending on the political party, and the leader selection adopt the 'one man one vote' system. It has made the candidates blindly to do everything they can to gain votes. This system does not differentiate between those who have extensive knowledge and those who do not. Therefore, there is no consideration based on the results of the analysis for good in the future but only based on the propaganda from third parties who have an interest. Hence, in order to make Indonesia better in the future, we should review the election system.

For this research to be more comprehensive, other studies that are in line with this study are needed. Researchers should study further when it appears that a society's phenomenon begins to show understandings of the caliphate. The researcher must immediately find the reasons for the emergence of such social movements so that the desire to establish a caliphate does not develop.

\section{Conclusion}

Based on the explanation described in this article, we can conclude that Pancasila represents the ideology of Indonesian nation, which reflects the nation's culture. Historically, Pancasila originates from the values and habits of Indonesian society that all Indonesian society will accept. Conceptually, the ideology of Pancasila is in tune with the Islamic law.

\section{Acknowledgements}

The authors would like to thank Zaenuddin Hudi Prasojo for their private review of the article's substantiation and Elmansyah Elmansyah for their review, translation and editing according to the journal's requirement.

\section{Competing interests}

The authors declare that they have no financial or personal relationships that may have inappropriately influenced them in writing this article.

\section{Authors' contributions}

P.H. conceived of the presented idea, developed the theory and wrote the article. A.F. verified the analytical methods and encouraged P.H. to investigate, and supervised the findings of this work. Both authors discussed the results and contributed to the final manuscript.

\section{Ethical considerations}

This article followed all ethical standards for research without direct contact with human or animal subjects.

\section{Funding information}

This research study received no specific grant from any funding agency in the public, commercial or not-for-profit sectors.

\section{Data availability}

Data sharing is not applicable to this article as no new data were created or analysed in this study.

\section{Disclaimer}

The views and opinions expressed in this article are those of the authors and do not necessarily reflect the official policy or position of any affiliated agency of the authors.

\section{References}

Ahyar, M., 2018, 'Almawardi dan Konsep Khilafah Islamiyyah: Relevansi Sistem Politik Islam Klasik dan Politik Modern', Al-A'raf: Jurnal Pemikiran Islam Dan Filsafat 15(1), 1-26. https://doi.org/10.22515/ajpif.v15i1.1123

Ali, A.R., 1985, Khilafah dan Pemerintahan Dalam Islam, Pustaka, Bandung.

Al-Maududi, A.A.A., 1984, Khilafah dan Kerajaan: Evaluasi Kritis Atas Sejarah Pemerintahan Islam, in T. M. Baqir (ed.), Mizan, Bandung.

Al-Maududi, A.A.A., 1995, Hukum dan Konstitusi: Sistem Politik Islam, T.A. Hikmat (ed.), Mizan, Bandung.

Al-Nabani, T., 1996, Nidham Al-Hukm Fi Al-Islam, Dar al-Ummah, Beirut Libanon. 
Amiruddin dan Asikin, 2004, Pengantar Metode Penelitian Hukum, PT Raja Grafindo Persada, Jakarta.

Andrews, W.G., 1968, Constitutions and constitutionalism, Van Nostrand Company, Princeton, NJ.

Asshiddiqie, J., 2005, Konstitusi dan Konstitusionalisme Indonesia, Konstitusi Press, Jakarta.

Baidhawy, Z., 2010, 'Dinamika Radikalisme dan Konflik Bersentimen Keagamaan di Surakarta', Studia Philosophica et Theologica 10(2), 258-287.

Baidhowi, 2016, 'Khilafah Dalam Konteks Negara Pancasila', Seminar Nasional Hukum 2(1), 497-516.

Engineer, A.A., 1999, Asal-Usul dan Perkembangan Islam Analisis Pertumbuhan Sosial Ekonomi, Cetakan ke, Pustaka Insist, Yogyakarta.

Hidayat, K., 2014, Kontroversi Khilafah: Islam, Negara Dan Pancasila, Mizan, Bandung. Ismaun, 1983, Tinjauan Pancasila Dasar Filsafat Negara Republik Indonesia, CV Carya Remaja, Jakarta.

Jaelani, J., 2015, 'Kontroversi Khilafah: Islam, Negara, Dan Pancasila', Jurnal Sosioteknologi 14(2), 201-204. https://doi.org/10.5614/sostek.itbj.2015.14.2.9
Kaelan, 2017, Inkonsistensi dan Inkoherensi Dalam Undang-Undang Dasar Negara Republik Indonesia Tahun 1945 Hasil Amandemen: Kajian Filosofis Dan Yuridis, Badan Pengkajian Majelis Permusyawaratan Rakyat RI, Jakarta.

Kholdun, I., 2000, Muqaddimah Ibn Kholdun, Cetakan Pertama, Pustaka Firdaus, Jakarta.

Misrawi, Z., 2011, 'Rethinking pluralisme: Telaah konsep dan implementasinya dalam kehidupan sosioreligius di Indonesia', Jurnal Dialogia 9(1), 5-28.

Muhammad Mahfud, M.D., 2012, 'Strategi Pelembagaan Nilai-Nilai Pancasila Dalam Menegakkan Konstitusionalitas Indonesia', in Kongres Pancasila IV, p. 2, Pusat Studi Pancasila, Yogyakarta.

Munadzir, M., 2017, 'Konsep Kepemimpinan Menurut Syu'bah Asa', Al-A'raf: Jurna Pemikiran Islam dan Filsafat 14(2), 253-266. https://doi.org/10.22515/ajpif.v14i2.891

Nashir, H., 2013, Islam Syariat: Reproduksi Salafiyah Ideologis Di Indonesia, Mizan dan Maarif Institute, Bandung.

Notonagoro, 1980, Pancasila Secara Ilmiah Populer, Pantjuran Tujuh, Jakarta.

Poespowardojo, S., 1989, Filsafat Pancasila, Gramedia, Jakarta.

Shihab, M.Q., 2007, Tafsir Al-Misbah: Pesan, Kesan Dan Keserasian Al-Qur'an, vol. 2, Lentera Hati, Jakarta. 